\title{
Domestic Initiatives in a Global Context? Japan's Approaches to the Emissions Trading Schemes for the International Climate Change Regime
}

\section{Osamu Yoshida*}

Although in 2011 Japan finally decided not to participate in the second commitment period of the Kyoto Protocol to the United Nations Framework Convention on Climate Change, under the principles of sustainable development and common but differentiated responsibilities, it has probed the ways in which the 'ultimate objective' of the UNFCCC will be realized in the international community. With regard to socalled 'emissions trading,' since the middle of the 2000s, Japan has continuously adopted various methods and approaches for domestic emissions trading at local and central government levels. This article analyzes Japan's recent efforts in introducing emissions trading schemes and finally refers to the Joint Crediting Mechanism, which covers the period until a future new agreement under the UNFCCC comes into effect.

\section{Keywords}

JVETS, Emissions Trading, Emissions Trading Scheme, Kyoto Protocol, UNFCCC, Joint Crediting Mechanism

* Professor of public international law at the University of Tsukuba. Dr. Phil. (Edinburgh). Research Fellow at the University of Tokyo (1999-2000); Visiting Fellow at the Institute of International Law and International Relations, Vienna University (2003-2004). He has served as a Member of the I.L.A. Committee on the Legal Principles relating to Climate Change. The author may be contacted at: yoshida.osamu.gn@u.tsukuba.ac.jp / Address: Faculty of Humanities and Social Sciences, University of Tsukuba, 1-1-1 Tennodai, Tsukuba, Ibaraki, 3058571 Japan. 


\section{Introduction}

As a party to both the United Nations Framework Convention on Climate Change of 1992 ("UNFCCC") ${ }^{1}$ and the Kyoto Protocol of 1997, ' Japan has legislated domestic laws concerning climate change, in order to implement the international treaties under international law. ${ }^{3}$ These laws include: ${ }^{4}$ the Law Concerning the Promotion of the Measures to Cope with Global Warming; ${ }^{5}$ the Act on the Rational Use of Energy; ${ }^{6}$ the Act on Special Measures for the Promotion of New Energy Use, etc. ${ }^{7}$ the Act on Special Measures for the Use of New Energy Use etc. by Electricity Business; ${ }^{8}$ the Act on Ensuring the Implementation of Recovery and Destruction of Fluorocarbons concerning Designated Products. ${ }^{9}$ Unlike some other countries, e.g., South Korea, New Zealand and Australia, ${ }^{10}$ a nation-wide scheme on 'emissions trading ${ }^{11}$ has not

1 United Nations Framework Convention on Climate Change, May 9, 1992, S. Treaty Doc No. 102-38, 1771 U.N.T.S. 107.

2 Kyoto Protocol to the United Nations Framework Convention on Climate Change, Dec. 10, 1997, U.N. Doc FCCC/ CP/1997/7/Add.1, reprinted in 37 I.L.M. 22 (1998). Japan decided not to participate in the second commitment period of the Kyoto Protocol (2013-20) and hence in this period it can only be eligible to transfer and acquire certified emission reductions. For details see Report of the Conference of the Parties serving as the Meeting of the Parties to the Kyoto Protocol on its Eighth Session, Nov. 26 - Dec. 8, 2012, Decision 1/CMP.8, 15, at 4, U.N. Doc. FCCC/KP/ CMP/2012/13/Add.1 (Feb. 28, 2013). See Ministry of Foreign Affairs of Japan, Japan's Position regarding the Kyoto Protocol (Dec. 2010), available at http://www.mofa.go.jp/policy/environment/warm/cop/kp_pos_1012.html (last visited on Oct. 9, 2014).

3 See, e.g., Yuji Iwasawa, International Law in the Japanese Legal Order: Recent Developments, 91 Proceedings of Annual Meeting-American Society of International Law 301-307 (Apr. 9-12, 1997).

4 See e.g. Tadashi Otsuka, Chikyū Ondanka Wo Meguru Hō Seisaku [Law and Policy on Global Warming) < available only in Japanese> 60-83 (2004).

5 Chikyū ondanka taisaku no suishin ni kansuru hō [Law Concerning the Promotion of Measures to Cope with Global Warming], Law No. 117 of 1998.

6 Enerugi no shiyō ni kansuru hōritsu [Act on the Rational Use of Energy], Law No. 49 of 1979.

7 Shin enerugī riyō tou ni kansuru tokubetsu sochi hō [Act on Special Measures for the Promotion of New Energy Use, etc.], Law No. 37 of 1997.

8 Denki jigyōsha ni yoru shin enerugi tou no riyō ni kansuru tokubetsu sochi hō [Act on Special Measures for the Use of New Energy Use etc. by Electricity Business], Law No. 62 of 2002.

9 Tokutei seihin ni kakaru furonrui no kaishū oyobi hakai no zisshi no kakuho tou ni kansuru hōritsu [Act on Ensuring the Implementation of Recovery and Destruction of Fluorocarbons Concerning Designated Products], Law No. 64 of 2001.

10 See, e.g., Legal Aspects of Implementing The Kyoto Protocol Mechanisms: Making Kyoto Work, chs. $23-29$ (D. Freestone \& C. Streck eds., 2005); Hitomi Kimura, Haishutsu Waku Torihiki wo meguru Saikin no Dōkō to Shōrai Wakugumi ni okeru Kadai [Recent Developments of Emissions Trading and the Problems in a Future Framework], 37 KANKYŌHŌ KenKYū [EnVtL L. J.] <available only in Japanese> 12-18 (2012).

11 See generally M. Schröder, Emission Trading, 3 Max Planck Encyclopedia of Public International Law 400-406 (R. Wolfrum ed., 2012). 